\title{
Scholars and Literati at the University of Valladolid $(1280-1800)$
}

\author{
David de la Croix Soraya Karioun \\ IRES/LIDAM, UCLouvain
}

In this note, we provide a summary description of the set of scholars and literati who taught at the University of Valladolid since its inception in the 13th century to the eve of the Industrial Revolution (1800).

\section{The UnIVERSITY}

Founded during the 13th century, the University of Valladolid is one of the oldest and most important universities in Spain. The university provided a home for professors and students, at a time when higher education was scattered all over the country, and provided a secular education, in a place where abbeys and episcopal establishments were predominant. With the support of the king and, later, the pope, the university built up a solid reputation intellectually, but also economically and culturally, while it closely participated in the development of the city (Fernández and González 1986). Unlike most old and prestigious universities elsewhere in Europe, the university of Valladolid was not implacably hostile towards the Jesuits, and permitted some Jesuits to fill university positions (Grendler 2019).

\section{SOURCES}

The three-volume book « Historia de la Universidad de Valladolid » was written by Mariano Alcocer Martínez, a Spanish historian, archivist, and bibliographer. The third volume deals exclusively with the professors of the university. The author provides a complete historical picture through vacancies and appointments between 1404 and 1832, followed by a methodological presentation of the professors' biographies (Alcocer Martinéz 1918). To complete the biographies provided in Alcocer Martinéz (1918), we have used the dictionary by the Real Academia de la Historia (2020), and the (monumental) work by Sommervogel (1890) for the Jesuits.

\section{Some Statistics}

Table 1 shows some descriptive statistics. There is a total of 842 scholars and literati. The number of observations per period shows that we do not know much about the early two centuries of the university. The year of birth is known for $16.9 \%$ of them. The mean age at appointment is 33.9 years, stable or decreasing over time. Longevity (mean age at death \& expected age at death when 30) is high during the early periods, probably because of a selection effect (the footprint of those who died young has been lost). Longevity improves in the last two periods, with a gain of about three years (roughly, from 64 to 67). The birthplace is known for half of the individuals. The median distance between their birthplace and Valladolid is $205 \mathrm{~km}$, reflecting that few people came from around Valladolid, and mobility seems to have been high within Spain. Finally, 6.7\% of the scholars have a Wikipedia page (in some language), and $12.7 \%$ of them have left a footprint in the catalogues of the libraries of the world, Worldcat, either by having published work, or by having been the subject of published books and articles. 


\begin{tabular}{|c|c|c|c|c|c|c|}
\hline \multicolumn{2}{|c|}{ Period } & \multirow{2}{*}{$\begin{array}{l}\text { nb. } \\
\text { obs }\end{array}$} & \multirow{2}{*}{$\begin{array}{l}\% \text { birth year } \\
\text { known }\end{array}$} & \multirow{2}{*}{$\begin{array}{l}\text { mean age } \\
\text { at appoint. }\end{array}$} & \multirow{2}{*}{$\begin{array}{l}\text { mean age } \\
\text { at death }\end{array}$} & \multirow{2}{*}{$\begin{array}{l}\text { exp. age } \\
\text { at death }\end{array}$} \\
\hline Start & End & & & & & \\
\hline 1200 & 1347 & 1 & 100 & 25.0 & 76.0 & 77 \\
\hline 1348 & 1449 & 4 & 50 & 45.5 & 70.5 & 71.5 \\
\hline 1450 & 1526 & 29 & 17.2 & 45.8 & 72.8 & 70.3 \\
\hline 1527 & 1617 & 286 & 19.2 & 32.6 & 65.6 & 67.3 \\
\hline 1618 & 1685 & 211 & 17.1 & 33.2 & 64.5 & 64.3 \\
\hline 1686 & 1733 & 131 & 13.7 & 34.8 & 68.5 & 69.7 \\
\hline 1734 & 1800 & 180 & 13.9 & 34.3 & 67.0 & 66.5 \\
\hline \multirow[t]{3}{*}{1000} & 1800 & 842 & 16.9 & 33.9 & $6 \overline{6} . \overline{3}$ & 67.4 \\
\hline & & & $\%$ birthplace & median distance & $\%$ with & \% with \\
\hline & & & known & birth-institution & Wikipedia & Worldcat \\
\hline 1200 & 1347 & & 100 & 115 & 100 & 100 \\
\hline 1348 & 1449 & & 50 & 27 & 25.0 & 25.0 \\
\hline 1450 & 1526 & & 93.1 & 129 & 24.1 & 24.1 \\
\hline 1527 & 1617 & & 62 & 202 & 10.1 & 11.5 \\
\hline 1618 & 1685 & & 46.4 & 200 & 4.3 & 13.7 \\
\hline 1686 & 1733 & & 43.5 & 224 & 3.1 & 13.7 \\
\hline 1734 & 1800 & & 29.6 & 210 & 2.8 & 10.0 \\
\hline 1000 & 1800 & & 49.4 & 205 & 6.7 & 12.7 \\
\hline
\end{tabular}

Table 1: Summary statistics by period

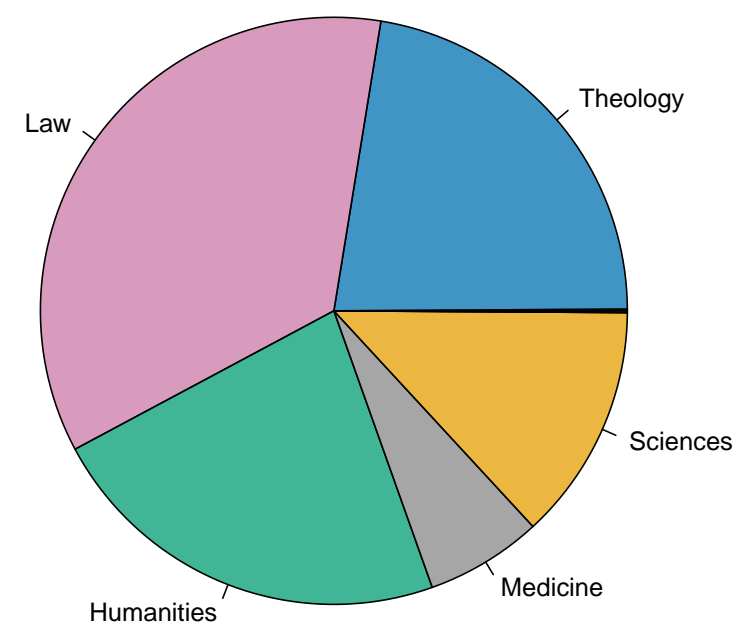

Figure 1: Broad fields at Valladolid 


\section{FIELDS}

Figure 1 shows the relative importance of fields, broadly defined. In its early days, the University of Valladolid was an institution directed towards general studies. The main subjects, such as Grammar or Mathematics, were taught, excluding the theological field, which remained the exclusive domain of the University of Paris. It was not until 1418 that Pope Martin V granted the city a faculty of theology. At the same time, the faculty of law grew significantly and this field became one of the main subjects taught at Valladolid. Unfortunately, the 15th century marked the beginning of the decline of the university. It reached a low in the 17th century and, as a result, the quality of education and the number of fields taught decreased. It was not until the second half of the 18th century that science education was developed (Fernández and González 1986).

\section{Place of Birth}

Figure 2 is a plot of the places of birth of all the scholars involved with the University of Valladolid: it shows the very Spanish nature of this university. Exactly no one was hired at the University of Valladolid from outside the Spanish peninsula and islands.

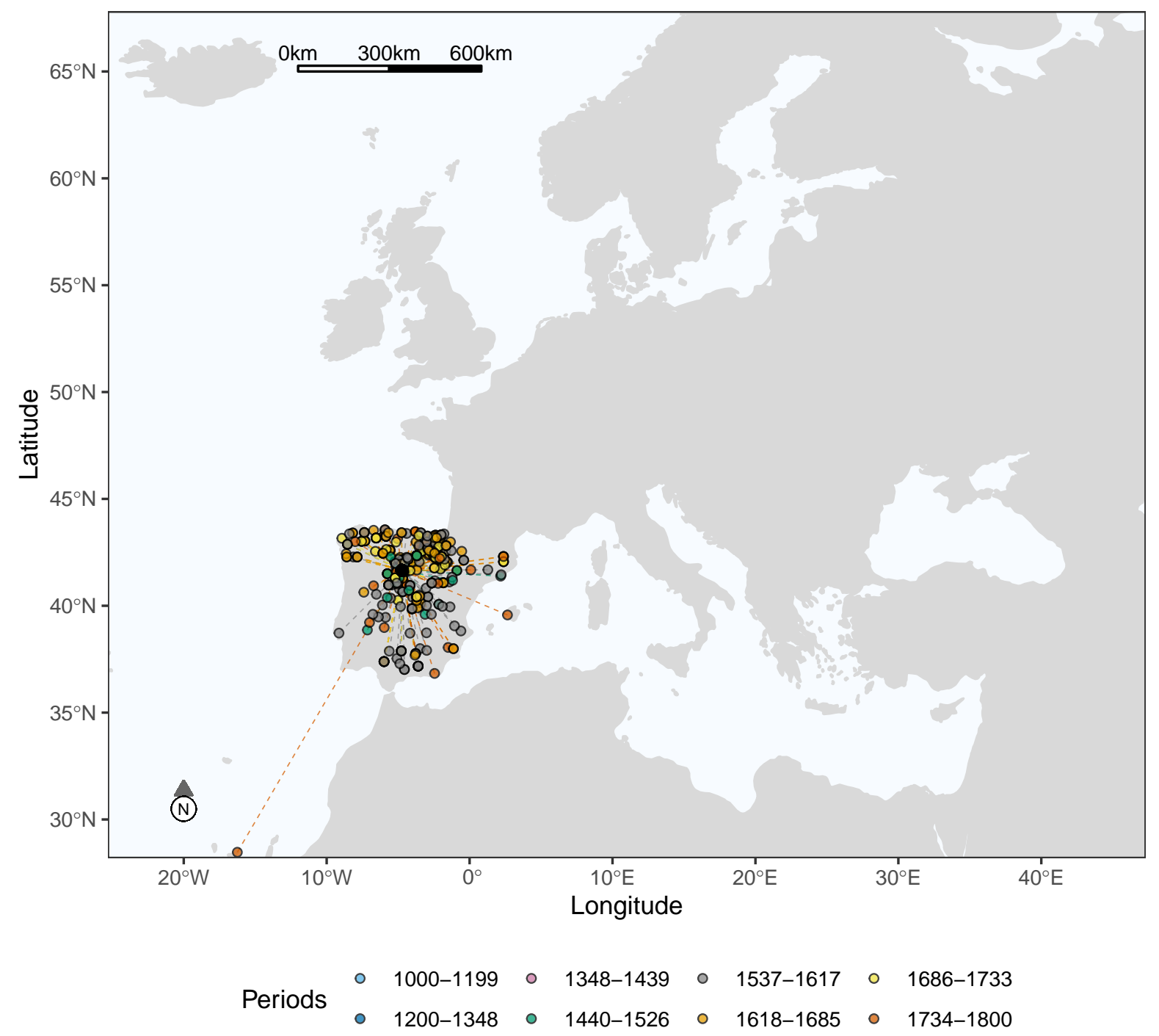

Figure 2: Place of birth of the scholars and literati at the University of Valladolid 


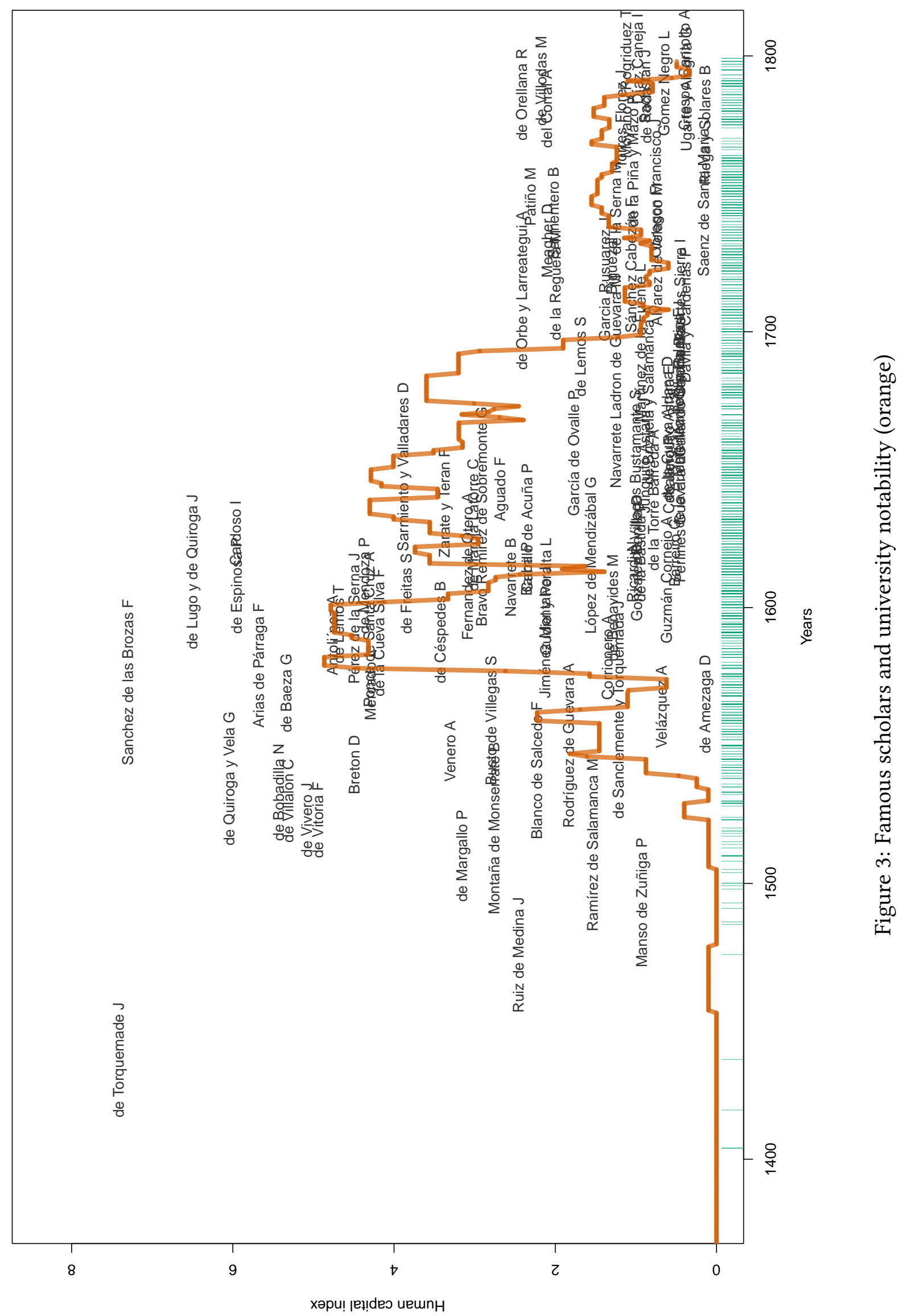




\section{Human Capital of Scholars and Literati}

For each person in the database, we compute a heuristic human capital index, identified by combining information from Worldcat and Wikipedia using a principal component analysis. We also compute the notability of the university at each date by averaging the human capital of the scholars active in Valladolid 25 years before that date. Details are given in the Appendix. Figure 3 shows the names of all the scholars with a positive human capital index. The orange line plots the notability of the university. The vertical green lines (rug plot) show the distribution of all scholars, including the obscure ones, over time.

The pattern is interesting. The university starts out very modestly for some centuries. Then there is the Spanish Golden Age with a wealth of well-regarded scholars. Notability is high from 1560 to 1680 . This apogée is followed by a marked decline, not because fewer people are registered in our database, but because those people did not publish much compared to their predecessors.

\section{Top 6 Professors}

Here, we provide a brief overview of the six professors with the highest human capital index.

Juan de Torquemada (Torquemada 1388 - Rome 1468) was a Dominican cardinal, doctor in theology at the University of Paris, where he taught for a year. He was one of the first professors at the newly inaugurated Faculty of Theology of Valladolid, before going to Rome to teach for several years. He was a fervent defender of the pope's authority, took part in the Council of Florence and, notably, participated in the condemnation of Jean Hus and John Wyclif.

Francisco Sanchez de las Brozas (Brozas 1523 - Salamanca 1600), also known as Le Brocense or Sanctius, was a humanist, philologist, and grammarian from a modest family. A professor of rhetoric at the University of Valladolid in 1573, he gave up his chair in 1579 to devote himself to his work after obtaining his doctorate. He continued teaching at the University of Salamanca until his death. His boldness, eclectic teaching methods, and acerbic remarks about theologians brought on three confrontations with the Inquisition, which led to a restriction of the distribution of his work.

Juan de Lugo y de Quiroga (Madrid 1583 - Rome 1660) was a Jesuit theologian. Noticed from an early age for his intellectual precocity, he completed his apprenticeship with the Jesuits before going to Salamanca to study law and canon. He taught theology at Valladolid from 1612 to 1616 and continued teaching at several Spanish universities before going to the Roman College in 1621, where he taught for twenty years. A remarkable intellectual and man of the cloth, he was named cardinal by Pope Urban VIII in 1643.

Gaspar de Quiroga y Vela (Madrigal de las Altas Torres 1512 - Madrid 1595) mostly distinguished himself through his ecclesiastical career. After having been the Bishop of Cuenca and then the Archbishop of Toledo, he was named cardinal by Pope Gregory XIII in 1578. He was also a General Inquisitor of Spain from 1573 to 1587. Educated in law and a doctor in theology, he occupied the chair of Vespers in 1538 at the University of Valladolid.

Isaac Cardoso (Celorico 1604 - Verona 1683), originally from a Portuguese Jewish family, was baptised Fernando after his family moved to Spain and converted to Christianity. He studied philosophy and medicine in Salamanca and then taught both disciplines in Valladolid. He is the author of numerous books, both philosophical and medical. His knowledge is recognised for its eclecticism but also for the rigour of his argumentation.

Pedro de Espinosa (Antequera 1578 - Sanlucar de Barrameda 1650) was an illustrious poet and anthologist, a member of the Antequera-Granada school of poetry. He obtained a degree in either canon or theology and then taught philosophy for a year at Valladolid. His life was full of twists and turns: a traveller and lyricist, he later became a priest and hermit. He remains one of the most outstanding artists of his time due to the abundant poetic work that he wrote. 


\section{RELATED SCHOLARS}

Beyond those who taught at Valladolid, several important individuals are related to the university. They probably did not occupy an official position at the university, but they were involved in teaching and/or research. Here, we show the related scholars with the highest human capital index. Those scholars are counted to establish all figures but Figure 3.

Francisco Suárez (Granada 1548 - Lisbon 1617) Of Jewish (converted) origin, he entered the Jesuit Society at sixteen. After teaching at the Jesuit College in Valladolid, he taught at different places, including Alcala and Salamanca, before moving more permanently to the university of Coimbra. He had the reputation of being the greatest metaphysician of his time. He also contributed to the philosophy of law, discussing the natural power of kings. His textbook Disputationes Metaphysicae was printed in tens of editions and was taught to students of southern Europe for the centuries to come.

Domingo Bàñez (Medina del Campo 1528 - Medina del Campo 1604) was a renowned Dominican theologian, from a Basque family. He studied philosophy and theology and obtained a doctorate in the latter discipline in 1565 at the University of Siguënza. Known as an accomplished professor, he might have taught theology at Valladolid from 1573 to 1576 (according to the Junius Institute (2013)), but also in Avila, Salamanca, and Alcala.

Abner de Burgos (Burgos 1270 - Valladolid 1346) was one of the oldest professors of the University of Valladolid according to Michaud (1811). A great scholar of his time, he mastered many disciplines such as astronomy, astrology, medicine, and theologian studies. He came to the University of Valladolid in 1295 as a professor of medicine, as he already mastered the discipline at the age of twenty-five. Educated in a strong Jewish tradition, he was first a rabbi before converting to Christianity and taking the name Alfonso de Valladolid. He then devoted much of his work to demonstrating the superiority of the Christian faith.

Rodericus Arriaga (Logroño 1592 - Prague 1667) was a Jesuit theologian, philosopher, and jurist. He taught philosophy at the Jesuit College of Valladolid (Sommervogel 1890) and theology at Salamanca. He lived most of his life in Prague, as a professor of theology and as the chancellor of the university afterwards. Respected for his knowledge, his ability to criticize and defend his theses with vivacity, he stood out as a brilliant representative of 17 th century Jesuit scholasticism.

\section{INTERSECTIONS With NeARBy UNIVERSities}

Among the 842 scholars of Valladolid, a vast majority does not appear on university rolls in the nearby universities of Salamanca, Alcala, Oviedo, and Santiago de Compostela. The Venn diagram shows that the intersection with the largest number of individuals is with the University of Salamanca, with $17(13+1+2+1)$ scholars. 2 scholars taught at the three universities, Salamanca, Valladolid, and Alcala. Intersections with the less known universities of Oviedo and Santiago de Compostela are minimal.

\section{UNIVERSITY NETWORK}

Here we assume that when a professor occupied a position in more than one university over his/her life, this established a link between those universities. The universities with which Valladolid is linked are displayed in Figure 5. The picture here shows some international character to the University, which was not apparent from the map with the places of birth.

\section{AnecDotes}

However well-documented Valladolid's history might be, one key piece of information is missing: the reason behind its creation. Three hypotheses are commonly put forward. For some, the univer- 


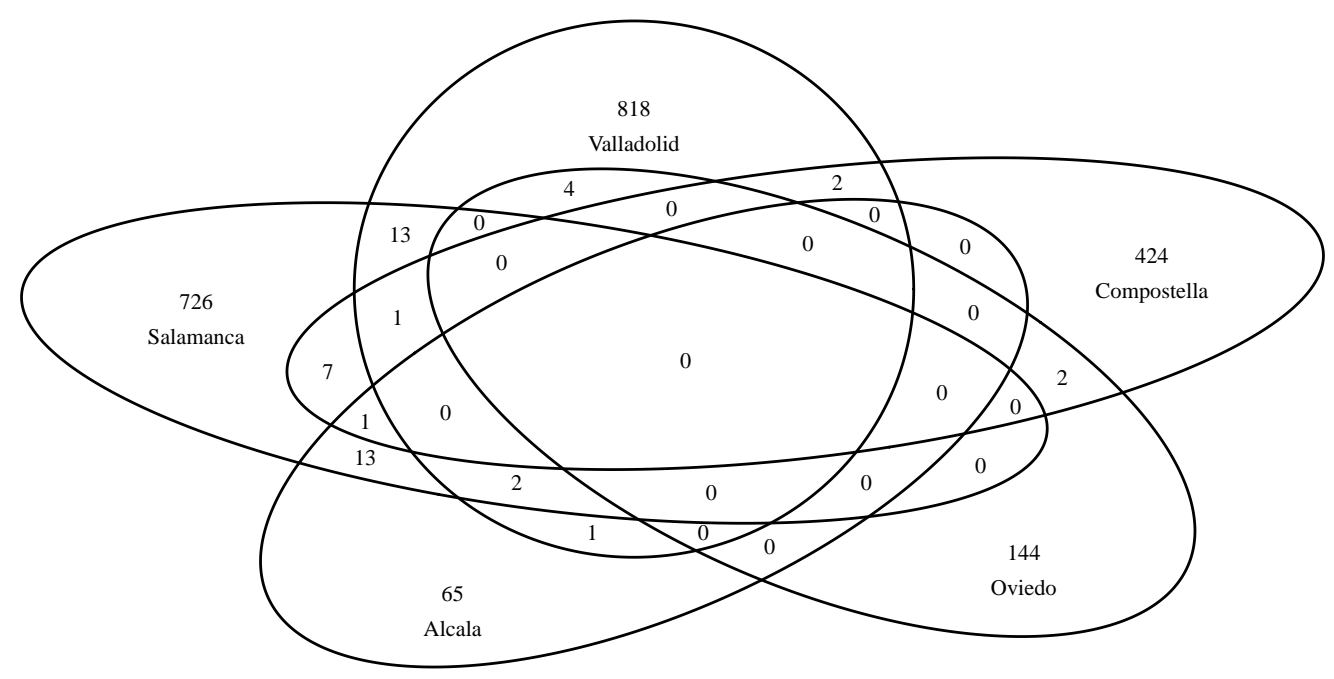

Figure 4: Intersections of the list of scholars between the main universities of Western Spain

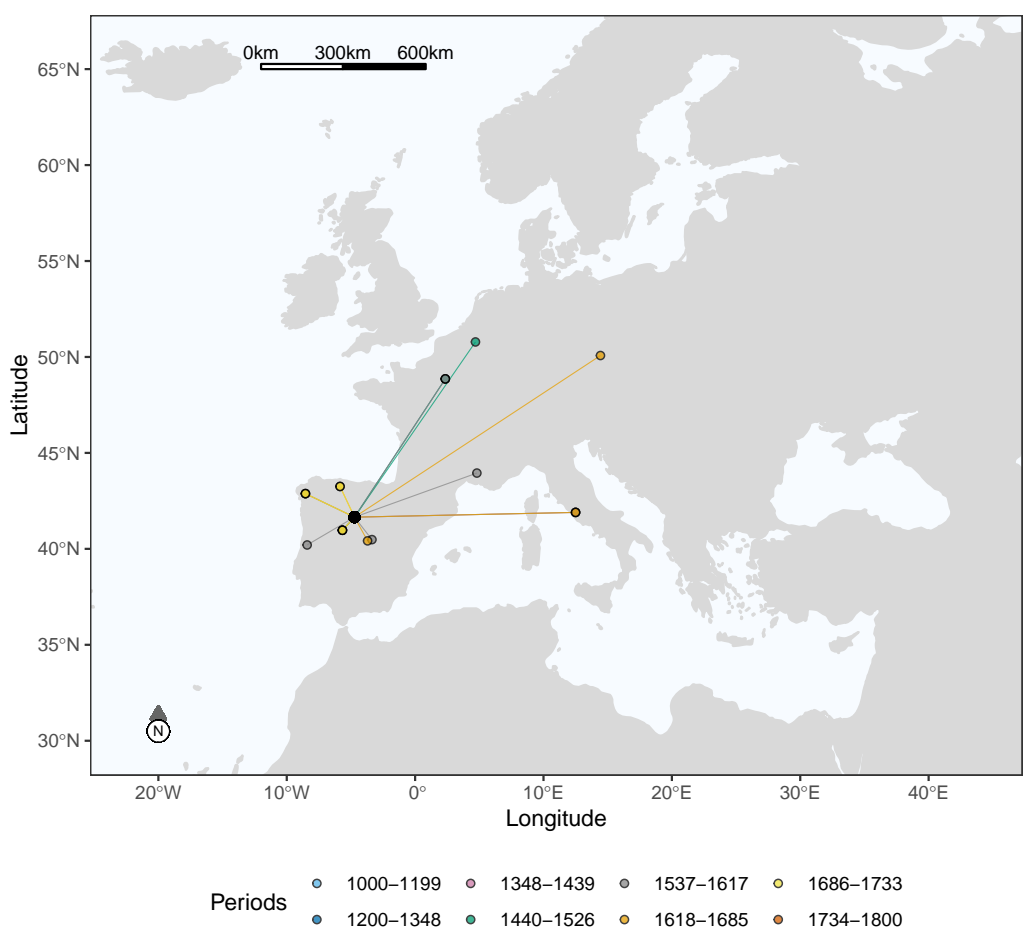

Figure 5: Links between Valladolid and other universities through scholars' mobility, by period

sity was founded when the University of Palencia closed due to lack of funding. For others, it could be the transformation of an episcopal school into a university. Finally, the most modern hypothesis claims that the creation of the university was a simple royal and municipal decision. In the end, the University of Valladolid has marked history through the legacy that it has left to the world, and not knowing the reason for its creation will not change that fact.

\section{APPENDIX}

The individual human capital index $q_{i}$ of an individual $i$ is given by:

$q_{i}=-1.76+0.43 \ln (\mathrm{nb}$. characters of the longest Wikipedia page) $+0.40 \ln$ (nb. wikipedia pages in different languages) $+0.47 \ln (\mathrm{nb}$. works in Worldcat) $+0.46 \ln (\mathrm{nb}$. publication languages in Worldcat $)+0.47 \ln (\mathrm{nb}$. library holdings in Worldcat) 
We assume that having no Wikipedia page is similar to having one page with a length of 60 characters and that having no Worldcat page is similar to having a page with one work in one language held by one library. The constant -1.76 normalizes $q_{i}$ at 0 when there is neither a Wikipedia page, nor a Worldcat page. The weights $(0.43,0.40$, etc) are obtained from the first principal component of the five indicators (De la Croix et al. 2020).

The notability $Q$ of a university aggregates the $q$ of the top 5 persons who were active in the preceding 25 years using the following formula:

$$
Q=\sqrt{\sum_{i=1}^{5} \frac{1}{5}\left(\frac{q_{i}}{s_{i}}\right)^{2}}
$$

where $s_{i}$ is the number of universities in which $i$ had an appointment.

\section{ACKNOWLEDGMENTS}

This project has received funding from the European Research Council (ERC) under the European Union's Horizon 2020 research and innovation programme, under grant agreement No. 883033 "Did elite human capital trigger the rise of the West? Insights from a new database of European scholars."

First version December 3, 2020. Updated September 4, 2021

\section{REFERENCES}

Alcocer Martinéz, Mariano. 1918. Historia de la Universidad de Valladolid - Expendientes de provisiones de catedras. Valladolid: Imprenta Castellana.

De la Croix, David, Frédéric Docquier, Alice Fabre, and Robert Stelter. 2020. "The Academic Market and the Rise of Universities in Medieval and Early Modern Europe (1000-1800)." CEPR Discussion Paper 14509.

Fernández, Celso Jesús Almuiña, and Juan José Martín González. 1986. La Universidad de Valladolid: historia y patrimonio. Universidad de Valladolid. Secretariado de Publicaciones e Intercambio Editorial.

Grendler, Paul F. 2019. Jesuit Schools and Universities in Europe 1548-1773. Brill Research Perspectives in Jesuit Studies. Brill.

Junius Institute. 2013. "Post Reformation Digital Library - Scholastica." Available at https://www. prdl.org.

Michaud, Joseph-François. 1811. Biographie universelle ancienne et moderne, 45 vols. Paris: Bureau de la Biographie Universelle.

Real Academia de la Historia. 2020. Diccionario biográfico español (online version at https:// dbe.rah. es). Madrid: Real Academia de la Historia.

Sommervogel, Carlos. 1890. Bibliothèque de la Compagnie de fésus. Brussels: Oscar Schepens. 